\title{
Development of Game Models in Physical Education to Support Thematic Learning in Grade 1 Elementary School
}

\author{
$1^{\text {st }}$ Spyanawati, Ni Luh Putu \\ Sports And Health Faculty \\ Ganesha University Of Education \\ Buleleng, Indonesia \\ spyanawati03@gmail.com
}

\author{
$2^{\text {st }}$ Dwi Sucita D, Ni Putu \\ Sports And Health Faculty \\ Ganesha University Of Education \\ Buleleng, Indonesia \\ dwi.sucita@undiksha.ac.id
}

\author{
$3^{\text {nd }}$ Semarayasa, I Ketut \\ Sports And Health Faculty \\ Ganesha University Of Education \\ Buleleng, Indonesia \\ ketut.semarayasa@undiksha.ac.ic
}

\begin{abstract}
The purpose of this study was to develop a game model in Physical Education to support thematic learning for grade 1 elementary school on the theme 3 "My Activities". The research method used is the R\&D method developed by Borg and Gall. This research only reaches the initial product development which has been validated by 3 validators consisting of design experts, content / material experts and field practitioners. The product of this research is in the form of a module "Thematic PJOK Game Class 1 My Activity Theme" with 8 types of games in it which are adjusted to the theme and sub-theme. The results of the validation test by the experts obtained the results, namely in terms of design, the percentage level of $92 \%$ was very good, in terms of content / material, the percentage level was $92 \%$ in the good category and from the practitioner's point of view, the percentage was $90 \%$ in the very good category. It can be concluded that the game model module in PJOK learning to support thematic learning for grade I in Elementary School on theme 3 My activity is feasible to be tested in small groups.
\end{abstract}

Keywords-Physical Education, integrated thematic, Game model.

\section{INTRODUCTION}

Physical Education is an integral part of education as a whole which aims to improve individuals organically, neuromuscularly, intellectually and emotionally through physical activity. The essence of physical education learning is physical activity, namely movement. Most studies suggest that the age for learning motion is most appropriate before adolescence. Childhood is the time to learn basic skills, while adolescence is the time used for refinement and refinement and to learn a wide variety of movement skills.

Physical Education as a field of study oriented to the needs of student movement can also be integrated with other fields of study such as mathematics, science, language, social studies and religion. Based on the needs analysis that has been carried out, it is explained by the teacher that Physical Education in schools has not been effective until now, although various efforts have been made to improve the curriculum and through teacher education and training. In addition to the above, Physical Education teachers also find it difficult to obtain reference books that are representative and accommodating as well as a lack of public understanding of the contribution of physical education as a tool in realizing the formation of a whole human being (physically, emotionally, intellectually and socially healthy).

Games are activities that dominate the upper class primary school curriculum. Children will spend time and energy playing for the pleasure they want. Games will develop children's physical abilities, a place to socialize with others, and develop cognitive understanding through the rules of play. Through playing, the nerves will be stimulated which causes the brain to become more active. The child's motor skills will be better trained and focused. In addition, social skills are also honed, especially in group games. Children will learn to adjust to their friends and their environment. Children can know and obey rules, solve problems, accept other people, cooperate and be responsible.

Another play function is a fun recreation for children. Children can channel their tension in a positive and fun way. Children who play games will get the following benefits: (1) benefits for the development of physical aspects, (2) benefits for the development of gross and fine motor aspects, (3) benefits for the development of social aspects, (4) benefits for the development of emotional aspects or personality, (5) benefits for the development of cognitive aspects, (6) benefits for sharpening sensory acuity, and (7) benefits for developing sports and dance skills. Playing is done with an interesting game. Various forms of play can be classified based on time, place, number of participants, age, gender and so on [1].

Based on the needs analysis study through observations and interviews of researchers with teachers who teach in elementary schools in Buleleng sub-district, especially those in the lower class (grade 1), where in Buleleng sub-district it consists of 9 clusters and each cluster there are 11 to 12 schools. Of the 20 Physical Education teachers who were observed and interviewed, 85\% (17 people) stated that the teacher had difficulty applying the Physical Education learning model for any given material, because the examples of games presented in the guidebook were still very limited. The teacher realizes that the characteristic of low grade children is to introduce material while playing. However, teachers have difficulty finding and using the right form of play for integrated Physical Education learning with other subjects. Meanwhile, from the results of the initial data analysis $100 \%$ (20 people) Physical Education teachers stated that they really 
need a game model module for Physical Education material for grade 1 elementary school students.

The development of thematic learning Physical education in elementary schools can be well received and can be carried out well and can be used as a reference in physical education learning [2]. Other studies have also stated that game-based learning models are effective and can improve motor and cognitive abilities of students aged 9-10 years [3]. From several journals, it is stated that the game model is very effective for elementary school students, but the module for the game model in elementary schools has not been fully provided. Therefore, it is deemed necessary for researchers to provide a module of game forms for elementary school teachers and students, especially grade 1 elementary school students.

\section{METHOD}

This study uses the Research and Development (R\&D) method. Basically, $R \& D$ research has the characteristics of a product that results from its research. The product manufacturing model in this development research is the Borg $\&$ Gall model which consists of 10 stages [4]. The choice of this model is based on the consideration that there is a match between the development method and the product being developed. The advantage of the Borg \& Gall model itself is that it is able to produce a product that has a high validity value, because it has gone through a series of field trials and expert validation. The following is a picture of the stages of the Borg \& Gall Model.

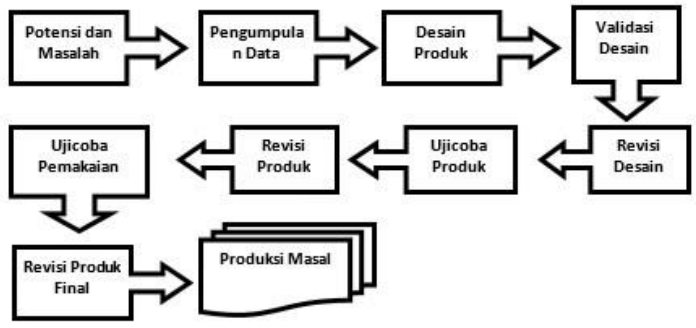

\section{RESULT AND DISCUSSION}

The initial product development process starts from analyzing the Teacher's Book and Student's Book. The theme book "My Activities" is divided into 4 sub-themes, namely: (1) morning activities, (2) daytime activities, (3) afternoon activities, and (4) evening activities. Each sub-theme is further divided into 6 learning activities, namely learning activities 1 to 6. Physical education learning for each sub-theme appears in 2 learning activities, namely learning activities 2 and learning activities 4 .

After identifying the basic competencies and structure of the My Activity theme book, the next step is to create physical education activities that are in accordance with the basic competencies and structure of each sub-theme. Physical education is identical to physical activity or movement which characterizes it so that learning activities are designed in the form of games. The game was chosen considering the characteristics of children aged 6-7 years, one of which is playing. Through play activities, children will channel their excess energy, create knowledge through play and through games children learn to know and solve problems. The game chosen is a motion-based game in accordance with the characteristics of physical education.

The theme of My activities is divided into 4 sub-themes and physical education appears in 2 learning activities so that 1 game is designed for 1 learning activity. So that in this study, 8 forms of physical activity or motion games were designed. In the morning activity sub-theme there are 2 games, namely "Shoot and Arrange" and "Clap and Oper". In the subtheme of daytime activities there are games "Tunnel of Words" and "Fireball". Meanwhile, in the afternoon activity sub-theme there are games "Boom Basket" and "Airball". In the evening activity sub-theme, there are games "Bouncing Ball" and "Toxic Ball".

The validation test in this study used 3 experts, namely design / media experts, content / content experts and field practitioners.

a. Design Expert Validation Test Results

Data validation results by design experts include aspects (1) appearance, (2) attractiveness and suitability, and (3) product packaging. The data from the design expert validation test, namely from the display aspect, get a score of 14 with a percentage of $93 \%$, meaning that the quality of the display is very good, from the aspect of attractiveness and suitability a score of 26 out of 30 is obtained with a percentage level of $87 \%$ in the good category Meanwhile, the product packaging aspect obtained a score of 14 with a percentage of $93 \%$ which describes the quality of the product packaging as very good. Overall, in terms of product design, it gets a score of 55 or $92 \%$, which means that in terms of product design it is very good so that it can be used in initial product trials.

b. Content / Material Expert Validation Test Results

Data validation by content or material experts includes 3 aspects, namely (1) the suitability of the learning material with the curriculum (4 indicators), (2) game characteristics (10 indicators), and (3) internalized character (3 indicators). The data from the content / material expert validation test results are as follows from the aspect of the conformity of the learning material with the curriculum, the score is 18 with a percentage of $90 \%$ in the very good category. From the aspect of game characteristics, it is obtained a score of 47 with a percentage of $94 \%$ in the very good category. Meanwhile, from the aspect of internalized character, it was obtained a score of 13 with a percentage of $87 \%$ in the good category. Based on these data, the overall product from content / material experts gets a score of 78 out of a maximum score of 85 with a percentage of $92 \%$ in the very good category so that the game is feasible or can be used further in limited trials or small group trials. c. Field Practitioner Validation Test Results 
Data validation results by field practitioners include 3 aspects, namely (1) appearance, (2) relevance, and (3) conformity to the demands of learning. The data from the validation test results by field practitioners are as follows, from the display aspect, it gets a score of 16 with a percentage of $80 \%$ meaning that the quality of the display is good, from the aspect of relevance it is obtained a score of 32 out of 35 with a percentage level of $91 \%$ in the very good category. While the aspect of conformity with the demands of learning gets a score of 24 with a percentage of $96 \%$ in the very good category. Overall in terms of use in the field, a score of 72 or $90 \%$ is obtained, which means that in terms of use in the field it is very good so that it can be used in initial product trials.

The development of this game module aims to increase the types of activities that are suitable for thematic-based physical education activities through game activities. The development of this game module is based on the fact that there are few thematic-based physical education activities that teachers can use, especially in elementary schools in Buleleng District, in the learning process at school.

This product development is carried out by steps starting from a needs analysis, gathering information, designing the initial product and conducting expert validation. The physical education module products based on the thematic theme of My activity go through a validation process by 3 material experts, namely design experts, content / material experts, and field practitioners. $92 \%$ in very good category. This means that in terms of design, this product is suitable for further use in limited field trials or small group trials. The results of product validation by material experts obtained data that 8 games were developed, all of which were feasible or could be used for small group trials. Of the 8 games, 6 games fell into the very good category, namely Shoot and Compose (92\%), Basket Eggs (93\%), Fireball (93\%), Toxic Balls (91\%), Airball (91\%) and Tunnels. Words (91\%). Meanwhile, 2 games were in either category, namely Boom Basket $(89 \%)$ and Bounce Ball (88\%). From the results of the validation by field practitioners, it was found that the product was in the very good category (92\%) so it was suitable for use in small group trials.

The module consists of a cover, an introduction, how to use the module, a table of contents and 8 types of games. The module is divided into 4 main sub-themes where each subtheme consists of 2 games. The four (4) sub-themes are (1) Sub-theme: Morning Activities consist of Shoot and Chain and Clap games, (2) Sub-themes: Daytime Activities consist of Word Tunnel and Fireball games, (3) Sub-theme: Afternoon Activities consists of Boom Basket and Airball games, and (4) Sub-theme: Nighttime activities consist of Bouncing Ball and Toxic Ball games. Each game consists of the game title, the definition of the game, the objectives of the game, the playing field and how to play it. The effectiveness of the product being developed still needs to be carried out further research studies, namely by conducting small group trials, large group trials and implementation because in this research it is only at the stage of product development that has been validated by design experts, content / material experts and field practitioners.

Development of the integrated thematic learning model for Physical Education in Natural Sciences subjects in elementary schools which shows that overall the integrative thematic learning model is feasible to be used for the Physical Education learning process in primary schools where the average score of students' knowledge tests is 86.2 which is in the very category good [5]. Similar research was also carried out in developing the physical education learning model for grade II elementary schools where the product implementation of the average knowledge assessment was 82.63 (good), the average attitude assessment was 83.06 (good) and the average skill assessment was 82.75 (good) [6]. In line with that, other researchers state that the development of physical education thematic learning materials for grade $\mathrm{V}$ elementary school students can create effective learning, can be used to develop 3 learning domains (cognitive, affective, and psychomotor) optimally [7].

The selection of games as a model of physical education is based on the characteristics of grade 1 students who are still in the process of learning while playing. Playing is a learning activity that involves mind, social and physical interactions. From various research results as quoted from parentingforbrain.com that there are several benefits of playing activities, namely (1) stimulating brain development (2) increasing intelligence, (3) increasing creative thinking skills, (4) improving communication, vocabulary and language, ( 5) increase the ability to manage emotions, (6) develop social skills and empathy, (7) develop and develop physical and mental abilities, (8) teach life lessons, and (9) strengthen relationships with others [8]. The results of research conducted by Kusumawati showed that there was an effect of traditional games on the results of the basic movements of running, jumping and throwing in grade 2 students of SDN 2 Blitarejo, Lampung [9]. Meanwhile, research conducted by Jihad stated that the target play in Physical Education learning contributed $41 \%$ to emotional intelligence at SDN Mulyasari Sumedang [10]. The game method, namely the smart circuit game, has a significant effect on the learning outcomes of fourth grade students at SD Lakarsantri II / 473 Surabaya [11].

\section{CONCLUSION}

Based on the results of the research and discussion, it can be concluded that the development of an integrated thematicbased PJOK learning model in the form of "PJOK Game Modules for Grade 1 SD My Activity Theme" is feasible or can be used to continue in limited trials or small group trials.

\section{REFERENCES}

[1] Mayke Tedjasaputra. 2007. Bermain, Mainan, Dan Permainan Untuk Pendidikan Usia Dini. Jakarta: Gramedia.

[2] Maharani Fatima Gandasari. Pengembangan Model Pembelajaran Tematik Pendidikan Jasmani Olahraga Dan Kesehatan Untuk Sekolah Dasar. Jurnal Pendidikan Jasmani Indonesia, 15 (1), 2019, 22 27 
[3] Ian Alfian Riyanto, Agus Kristiyanto, 2016. Pengembangan Model Pembelajaran Keterampilan Motorik Berbasis Permainan Untuk Anak Sekolah Dasar Usia 9-10 Tahun, Jurnal Media Ilmu Keolahragaan Indonesia, Volume 6 No. 1, Juni 2016, PISSN : 2088-6802

[4] Tegeh, I Made Dan Jampel, I Nyoman. 2017. Metode Penelitian Pengembangan. Singaraja: UNDIKSHA

[5] Giartama, G., Hartati, H., Destriani, D., \& Victoriand, A. R. (2018). Pengembangan Model Pembelajaran Tematik Integratif Penjasorkes Pada Mata Pelajaran Ilmu Pengetahuan Alam Di Sekolah Dasar. Sebatik, 22(2), 167-171.

[6] Gandasari, M. F. (2019). Pengembangan Model Pembelajaran Tematik Pendidikan Jasmani Olahraga Dan Kesehatan Untuk Sekolah Dasar. Jurnal Pendidikan Jasmani Indonesia, 15(1), 22-27.

[7] Nurzaqi , Sulaiman - , Setya Rahayu (2015), Materi Pembelajaran Tematik Pendidikan Jasmani Olahraga Dan Kesehatan Untuk Siswa Sekolah Dasar, Journal Of Physical Education And Sport, Vol 4 No 1 (2015): June 2015

[8] Parenting For Brain. 2020. Importance Of Play - 9 Amazing Benefits \& Infographic Tersedia Pada Https://Www.Parentingforbrain.Com/Benefits-Play-LearningActivities-Early-Childhood/

[9] Oktaria Kusumawati, 2017. Pengaruh Permainan Tradisional Terhadap Peningkatan Kemampuan Gerak Dasar Siswa Sekolah Dasar Kelas Bawah, Jurnal Pendidikan Dan Pembelajaran Dasar,TERAMPIL. Volume 4 Nomor 2 Oktober 2017. 124142

Http://Www.Ejournal.Radenintan.Ac.Id/Index.Php/Terampil/A rticle/View/2221/1666

[10] Jihad, B. M. (2019). Pengaruh Permainan Target Terhadap Kecerdasan Emosional Dalam Pembelajaran Penjas (Penelitian PreEksperimen Terhadap SDN Mulyasari Sumedang) (Doctoral Dissertation, UNIVERSITAS PENDIDIKAN INDONESIA).

[11] Handayani, M. E., \& BUDIYONO, B. Pengaruh Metode Permainan Sirkuit Pintar Terhadap Hasil Belajar Matematika Siswa Kelas IV SD. Jurnal Penelitian Pendidikan Guru Sekolah Dasar, 6(3). 